\title{
Model Desain Pembelajaran Tematik Terpadu Kontekstual Untuk Meningkatkan Kebermaknaan Belajar Siswa SD
}

\author{
Mawardi, Naniek Sulistya Wardani, Agustina Tyas Asri Hardini, Firosalia Kristin \\ mawardi@staff.uksw.edu,wardani.naniek@gmail.com, \\ tyas.asri@staff.uksw.edu, firosalia.kristin@staff.uksw.edu \\ Pendidikan Guru Sekolah Dasar, FKIP, Universitas Kristen Satya Wacana
}

\section{The Instructional Design With Contextual Integrated Thematic Model To Improve Meaningful Learning For Elementary Students}

\begin{abstract}
This study aims to: 1) develop syntax of instructional contextual integrated thematic design models to improve the meaningful learning of elementary students; 2) describe an validity models; and 3) describe the level of effectiveness of the model. This $R \& D$ research consists of a preliminary study, model designing and developing to be validated by experts, the model testing. The preliminary field testing involved 4 teachers and 57 elementary students participants. The main field testing involved 8 teachers and 94 students. The research instrument are questionnaires and test. This research findings are: 1) the model steps includes: a) setting a theme; $b$ ) adding sub-themes; c) the analysis of SKL, KI, KD and making indicators; d) the making of nets of sub-themes; e) developing syllabus; $f$ ) developing RPP; $g$ ) compiling a fragment of the teacher's book; and h) developing fragments of student books; 2) the model validity level is in the very high category (86\%), the syllabus and lesson plans and the material are in the high category (69.8\%; 69\%); and 3) the meaningfulness of student learning has increased, namely in the preliminary field test increased from 49.49 in pretest to 69.44 in post-test, and in the broad field test, the value increased greater than 47.98 to 70.43 . The statistical test using the t-test ensures that the increase is significant, because the probability value (0.00) is smaller than the value of $\alpha=0.05$.
\end{abstract}

Keywords: $R \& D$, Instructional Contextual Integrated Thematic Design Model, Meaningful Learning

Article Info

Received date: 27 November 2018 Revised date: 15 Desember 2018
Accepted date: 22 Januari 2019

\section{PENDAHULUAN}

Pemberlakuan Kurikulum 2013 pada jenjang SD/MI secara bertahap memberikan cukup waktu bagi guru untuk mendesain pembelajaran tematik terpadu secara lebih bermakna. Pembelajaran tematik hakikatnya merupakan model pembelajaran yang memadukan beberapa mata pelajaran ke dalam tema (Trianto, 2009: 84). Peneliti asal Korea Kim, M. K., \& Cho, M. K. (2015: 3), menyatakan bahwa pembelajaran yang memadukan beberapa mata pelajaran berdasarkan suatu tema merupakan suatu kebutuhan untuk direalisasikan dalam pembelajaran. Penggunaan tema untuk mengaitkan beberapa muatan mata pelajaran dapat memberikan pengalaman bermakna kepada peserta didik (Kemendikbud, 2014: 16). Hal senada dikemukakan oleh Trianto (2011: 7) yang menyatakan penggunaan pembelajaran tematik terpadu dengan menggunakan tema yang sesuai dengan lingkungan sekolah maupun tempat tinggal akan memudahkan siswa memperoleh pengalaman langsung sehingga dapat menambah kekuatan untuk menerima, menyimpan, dan menerapkan konsep yang mereka pelajari dalam kehidupan sehari-hari. Pembelajaran tematik berfungsi memberikan kemudahan bagi peserta didik dalam memahami dan mendalami konsep yang tergabung dalam tema serta dapat menambah semangat belajar karena materi yang dipelajari merupakan materi yang nyata (kontekstual) dan bermakna bagi peserta didik (Kemendikbud, 2014: 15). Pembelajaran tematik seperti telah dipaparkan di atas relevan dengan teori perkembangan kognitif Piaget, yang menyatakan bahwa siswa usia sekolah dasar memasuki tahap operasional konkret. Pada usia ini, siswa memiliki tiga karakteristik yang menonjol, antara lain konkret, integratif, dan hierarkis 
(lihat Prastowo, 2014: 6). Keefektifan pembelajaran tematik yang dirancang sejalan dengan teori kognitif Piaget ini ternyata mampu memberikan pengaruh yang signifikan terhadap hasil belajar siswa sekolah dasar (Arifin, S, 2016; Rini, R., \& Mawardi, M, 2015).

Dalam pengimplementasian Kurikulum 2013, secara umum pemerintah hanya menetapkan rambu-rambu, selanjutnya guru mendesain sendiri pembelajarannya. Rambu-rambu yang ditetapkan pemerintah berupa Kompetensi Inti, Kompetensi Dasar, Tema, dan Sub Tema, serta buku guru dan buku siswa. Buku guru merupakan buku yang digunakan sebagai panduan guru dalam melaksanakan pembelajaran di kelas. Buku guru memuat informasi tentang model dan strategi pembelajaran yang digunakan sebagai acuan penyelenggaraan proses pembelajaran. Buku siswa merupakan buku yang digunakan sebagai panduan aktivitas pembelajaran. Buku siswa juga digunakan untuk melaksanakan kegiatan-kegiatan dalam proses pembelajaran yang diarahkan agar siswa lebih aktif dalam mengikuti proses pembelajaran melalui kegiatan mengamati, bertanya, menalar, mencoba, berdiskusi serta meningkatkan kemampuan berkomunikasi baik antar teman maupun dengan gurunya. Guru dapat mengembangkan atau memperkaya rancangan buku guru dan siswa ini sesuai dengan tujuan pembelajaran yang telah ditetapkan.

Ada sinyalemen bahwa praktik penerapan Kurikulum 2013 saat ini guru kurang kritis terhadap buku guru dan buku siswa yang digunakan. Hal ini disebabkan oleh kesibukan guru dalam mengajar, sehingga kurang memiliki perhatian untuk menganalisis buku guru dan buku siswa. Hasil analisis yang dilakukan peneliti terhadap buku siswa menemukan adanya kelemahan pada deskripsi tema dan sub tema, jika dilihat dari kacamata hakikat pembelajaran tematik terpadu. Misalnya buku siswa kelas 4, tema 4 Berbagai Pekerjaan, subtema 1 Jenis-jenis Pekerjaan, materi Pembelajaran 1 sampai 6 seharusnya membahas materi dengan mengacu pada subtema Jenis-jenis pekerjaan secara konkret. Kenyataannya subtema jenis-jenis pekerjaan masih sangat umum dan belum konkret, sehingga pembelajaran menjadi kurang bermakna. Untuk mengatasi kekurangbermaknaan pembelajaran ini guru dapat menambahkan sub-subtema pada pembelajaran 1 (hari pertama) sampai dengan pembelajaran 5 (hari ke lima) dengan sub-sub tema kontekstual. Contohnya konteks siswa yang bersekolah atau bertempat tinggal di lingkungan petani maka akan lebih bermakna bagi siswa jika dalam pembelajaran digunakan sub-subtema "Petani". Pembelajaran untuk semua muatan (misalnya terdiri dari muatan IPA, Matematika, dan Bahasa Indonesia) berisi konten dalam seting kehidupan petani. Dengan demikian pembelajaran lebih konkret, sesuai lingkungan peserta didik, dan yang paling utama pembelajaran akan lebih bermakna. Bagi guru yang kreatif, bahkan dapat memberikan kesempatan kepada siswa untuk memilih dan mengembangkan temanya sendiri berdasarkan konteks tempat tinggal atau sekolahnya (Sundayana, 2014: 19). Dengan kata lain, penambahan sub-subtema kontekstual ini menjadikan pembelajaran lebih bermakna. Pembelajaran yang bermakna akan menghasilkan pengalaman bermakna bagi siswa dan akan berdampak positif pada peningkatan hasil belajar siswa.

Berdasarkan uraian tentang permasalahan desain pembelajaran yang kurang memperhatikan kebermaknaan belajar siswa, maka penelitian dan pengembangan model desain pembelajaran tematik terpadu kontekstual penting untuk dilakukan, sehingga pada gilirannya akan meningkatkan pula hasil belajar siswa. Sejalan dengan urgensi penelitian seperti tersebut, maka tujuan khusus yang ingin dicapai adalah: 1) mendeskripsikan langkah-langkah model desain pembelajaran tematik terpadu kontekstual di SD, 2) mendeskripsikan tingkat validitas model desain pembelajaran tematik terpadu; dan 3) mendeskripsikan sejauhmana produk model desain pembelajaran tematik terpadu kontekstual dapat meningkatkan kebermaknaan belajar siswa.

\section{KAJIAN PUSTAKA}

Frasa desain pembelajaran hakikatnya merupakan pengembangan pembelajaran secara sistematis menggunakan teori-teori pembelajaran untuk menjamin kualitas pembelajaran (Sagala, 2005: 136). Lebih detail Joyoatmodjo (2011: 66) mengartikan desain pembelajaran sebagai upaya pengembangan secara sistematis komponen-komponen pembelajaran dengan menggunakan teori belajar tertentu. Dengan demikian sebenarnya desain pembelajaran merupakan upaya pengembangan secara sistematis berdasarkan teori belajar dan pembelajaran tertentu untuk menjamin kualitas pendidikan, sehingga istilah model desain pembelajaran dapat dipahami sebagai konkretisasi teori pengembangan pembelajaran secara sistematis dengan menggunakan teori pembelajaran tertentu 
untuk menjamin kualitas pembelajaran yang berisi prinsip-prinsip, konstruk, tujuan dan langkahlangkah.

Berkaitan dengan desain pembelajaran, tersedia berbagai model desain pembelajaran tematik, di antaranya model desain pembelajaran tematik webbed, yakni pembelajaran dirancang berdasarkan tema pengikat yang dikaji secara integratif lintas matapelajaran (Fogarty, 2009: 65). Mengacu desain pembelajaran tematik model webbed, kemudian dikembangkan berbagai model desain pembelajaran tematik integratif, di antaranya model Kemendikbud yang menyatakan bahwa desain pembelajaran tematik integratif merupakan rancangan pembelajaran yang berpusat pada tema sebagai pengikat berbagi kajian matapelajaran, yang mencakup langkah-langkah: 1) memilih tema;2) melakukan Analisis SKL, KI, kompetensi dasar dan membuat indikator; 3) membuat hubungan pemetaan antara kompetensi dasar dan indikator dengan tema; 4) membuat jaringan tema beserta KD dan indikator matapelajarannya; 5) menyusun silabus; dan 6) menyusun RPP Kemendikbud (2014: 17). Model lain dikemukakan oleh Trianto yang menyatakan bahwa desian pembelajaran tematik terpadu mencakup tahapan: 1) pemetaan kompetensi inti (KI), kompetensi dasar (KD) dan indikator; 2) pemetaan keterhubungan tema ke dalam KI, KD dan indikator; 3) menetapkan jaringan tema; 4) menyusun silabus pembelajaran tematik; dan 5) menusun RPP (Trianto, 2010: 143-176). Pendapat berbeda dikemukakan oleh Hosnan yang menyatakan bahwa dalam mendesain pembelajaran tematik integratif mencakup langkah: 1) pemetaan KD; 2) pengembangan jaring tema. Berkaitan dengan pengembangan jaring tema ini, Hosnan menambahkan bahwa sebaiknya tema dipilih sesuai dengan dunia sekitar siswa; 3) pengembangan silabus; dan 4) penyusunan RPP (Hosnan, 2014: 366). Mencermati tiga pendapat tersebut, nampak bahwa pandangan Kemendikbud lebih komprehensif dibandingkan yang lain, oleh karena itu penelitian $R \& D$ ini merujuk pandangan Kemendikbud.

Mengikuti konsep model yang dikemukakan Kemendikbud dan hakikat model desain pembelajaran yang telah dikemukakan, maka model desain pembelajaran tematik terpadu kontekstual dalam penelitian ini dirumuskan sebagai konkretisasi teori yang mendesain pembelajaran dimana konteks lingkungan siswa sebagai sub-sub tema pembelajaran yang berisi prinsip-prinsip, konstruk, tujuan dan langkah-langkah. Langkah-langkah desain pembelajaran tersebut adalah 1) memilih/menetapkan tema, 2) melakukan analisis SKL, KI, KD dan membuat indikator, 3) membuat hubungan pemetaan antara KD dan indikator dengan tema, 4) membuat jaringan KD, 5) menyusun silabus, dan 6) menyusun RPP. Tujuannya yaitu memberikan pedoman kepada guru dalam merancang dan mengembangkan pembelajaran tematik terpadu kontekstual, agar pembelajaran lebih bermakna. Secara skematik, model desain pembelajaran tematik terpadu kontekstual dapat dicermati dari gambar 1.

Penelitian sejenis tentang desain pembelajaran tematik integratif telah dilakukan oleh beberapa peneliti, yaitu: 1) penelitian yang dilakukan Hermawan (2015) tentang pengembangan model pembelajaran tematik di kelas awal sekolah dasar menunjukkan bahwa model layak digunakan dalam pembelajaran; 2) Penelitian yang dilakukan Munawaroh (2014) tentang pengembangan model pembelajaran tematik untuk mengembangkan keterampilan berpikir kritis siswa SD kelas rendah menunjukkan model cukup valid dengan tingkat presentase 95\%, dilihat dari kenaikan skor nilai pretest terhadap skor nilai post-test. Sehingga dinyatakan bahwa model pembelajaran tematik telah valid dan layak digunakan dalam pembelajaran; 3) penelitian Jamaluddin (2015) tentang pengembangan model pembelajaran tematik terpadu kontekstual bagi anak usia dini di TK dan KB menunjukan tingkat keefektifan mencapai presentase $\geq 90 \%$ dan siswa memberikan respon yang positif, simpulan akhir dinyatakan bahwa model pembelajaran tematik layak digunakan dalam pembelajaran; 4) penelitian yang dilakukan Fatchurrohman (2015) tentang pengembangan model pembelajaran tematik integratif eksternal dan internal di MI menunjukkan temuan bahwa guru nyaman dan cocok terhadap model yang dikembangkan dan hasil evaluasi yang baik, sehingga model pembelajaran tematik layak digunakan dalam pembelajaran; penelitian yang dilakukan Pringgondani (2017) tentang pengembangan model desain pembelajaran tematik integratif berbasis lingkungan, menemukan bahwa model desain pembelajaran tematik integratif berbasis lingkungan ini layak digunakan dan efektif dalam meningkatkan hasil belajar siswa.

Penelitian lain tentang penerapan model pembelajaran tematik integratif yang juga relevan dengan penelitian ini adalah penelitian tindakan yang dilakukan oleh Julianti \& Mawardi (2018) serta penelitian Kharisma \& Mawardi (2018). Penelitian Julianti \& Mawardi tentang peningkatan kebermaknaan belajar dan hasil belajar siswa kelas 1 SDN Gendongan 02 Kota Salatiga dengan 
menerapkan desain pembelajaran tematik integratif berbasis sub-subtema menemukan adanya peningkatan persentase jumlah siswa yang mencapai kategori bermakna dan sangat bermakna pada siklus 1 sebesar 90\% dan siklus 2 sebesar $100 \%$. Penelitian Kharisma \& Mawardi tentang Implementation of an environmental-based alternative integrative thematic model to increase meaningfulness and learning outcome, menemukan hasil: "...the results show that there is an improvement from cycle I to cycle II, in both meaningfulness and student learning outcomes. Therefore, the environmental-based alternative integrative thematic design can be used to improve learning meaningfulness and student learning outcomes"

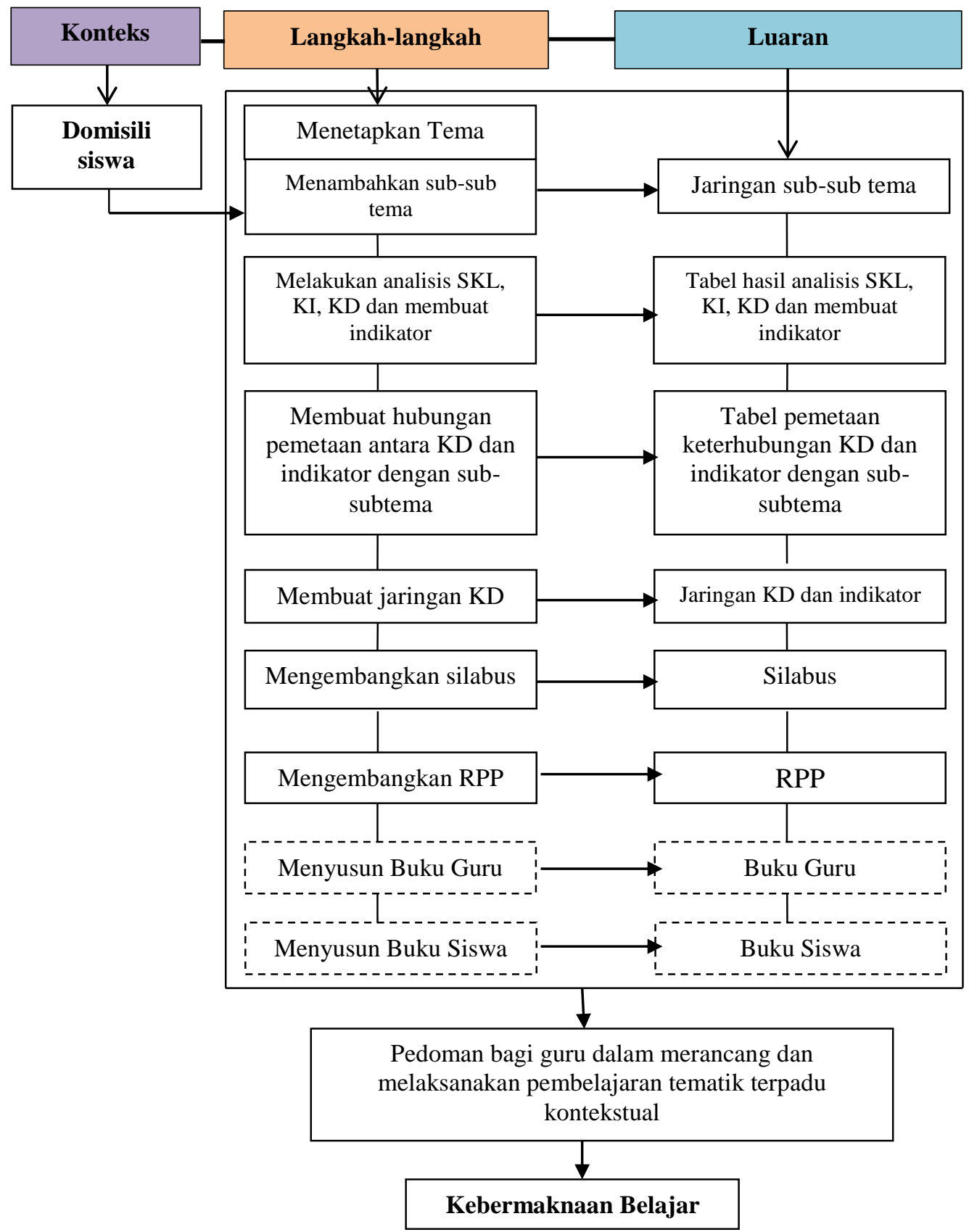

Gambar 1. Model desain pembelajaran tematik terpadu kontekstual

Penelitian yang dilakukan oleh Hermawan (2015), Munawaroh (2014) dan Fatchurrohman (2015) sama-sama melakukan penelitian dan pengembangan pembelajaran tematik, namun berbeda deengan penelitian ini. Penelitian pengembangan desain pembelajaran tematik terpadu kontekstual ini menempatkan variabel khusus konteks sekolah dan tempat tinggal siswa dijadikan sebagai subsubtema dalam pembelajaran, tujuannya agar siswa belajar lebih bermakna. Penelitian ini mirip 
dengan penelitian Jamaluddin (2015) tentang pengembangan model pembelajaran tematik terpadu kontekstual bagi anak usia dini di taman kanak-kanak dan kelompok belajar. Perbedaan prinsipiil terletak pada penambahan sub-sub tema yang tidak dilakukan oleh penelitian Jamaluddin. Demikian juga partisipannya bukan anak-anak TK dan KB, melainkan siswa SD yang berbeda taraf perkembangan kognitifnya. Perbedaan nyata dengan penelitian Pringgondani terletak pada variabel dampak yang dikembangkan, dalam penelitian ini variabel dampak (variabel Y) yang ditetapkan adalah kebermaknaan belajar, bukan hasil belajar, demikian juga seting temanya lebih spesifik, yaitu domisili siswa, bukan lingkungan secara umum. Penelitian lain yang mirip dengan penelitian ini adalah penelitian yang dilakukan Pringgondani (2017). Penelitian ini juga hampir sama dengan penelitian Julianti \& Mawardi (2018) dan penelitian Kharisma \& Mawardi (2018), yang meneliti tentang kefektifan model pembelajaran tematik integratif berbasis lingkungan, serta variabel dampaknya sama, yaitu tentang kebermaknaan belajar siswa, bedanya terletak pada perbedaan jenis penelitian yang digunakan, yaitu penelitian tindakan kelas, sedangkan penelitian yang dilakukan ini penelitian jenis R\&D.

Tentang pembelajaran bermakna, Koh, J.H.L. (2017: 136) menyatakan“...meaningful learning refers to learning that involves the active participation of students in experiences that are cognitively engaging ...". Pembelajaran bermakna mengacu pada pembelajaran yang melibatkan partisipasi aktif siswa dimana pengalaman pembelajaran tersebut menarik secara kognitif. Ketertarikan tentang pengalaman belajar mendorong siswa menghubung-hubungkan aspek-aspek, konsep-konsep, informasi, ataupun situasi baru dengan komponen-komponen relevan dalam struktur kognitif siswa, baik dalam bentuk hubungan yang bersifat derivatif, elaboratif, korelatif, suortif, atupun hubungan kualitatif representasional (Prastowo, 2013: 24). Dengan demikian pembelajaran bukan sekedar proses menghafal konsep, melainkan mengkaitkan berbagai konsep agar menghasilkan pemahaman yang utuh, sehingga tertanam kuat di benak siswa (Ardiani, N. F. W., Guna, N. A., \& Novitasari, R, 2013: 105). Pandangan dan temuan penelitian di atas relevan dengan pernyataan bahwa penggunaan tema sekitar siswa untuk mengaitkan beberapa matapelajaran dapat memberikan pengalaman bermakna pada siswa (Kemendikbud, 2014: 16). Lebih lanjut Sari, L. I., Satrijono, H., \& Sihono, S. dalam peneltiannya tentang pembelajaran tematik terpadu yang yang dikaitkan dengan lingkungan siswa dapat membantu siswa bersemangat dan termotivasi untuk belajar (Sari, L. I., Satrijono, H., \& Sihono, S. 2015: 13). Demikian juga peneliti internsional John,Y.J. (2015: 172) yang meneliti tentang implementing the new thematic menyatakan dalam simpulannya: "... findings from the study revealed prospective teachers were more effective in meeting the needs of all students while implementing the new thematic, integrated curriculum when trained compared to the prospective teachers implementing the curriculum without training.."

Kebaruan model desain pembelajaran tematik terpadu kontekstual dibandingkan dengan penelitian sejenis adalah bahwa penelitian ini memadukan beberapa muatan pelajaran sekaligus ke dalam pembelajaran. Muatan pelajaran yang dipadukan adalah muatan pelajaran PPKn, Bahasa Indonesia, IPS, IPA, Matematika, Seni Budaya dan Prakarya, serta Pendidikan Jasmani, Olah Raga dan Kesehatan. Siswa berpartisipasi dalam menamai sub-sub tema tambahan dalam pembelajaran ke1 sampai dengan ke-5 sesuai konteks mereka. Tujuannya agar pembelajaran di kelas lebih bermakna karena sesuai dengan konteks nyata siswa. Sub-sub tema yang dikembangkan sama sekali tidak merubah tema maupun subtema yang telah ditetapkan pemerintah, namun peneliti menamai dan mengembangkan pembelajaran 1 sampai 5 yang belum spesifik dan masih abstrak menjadi lebih spesifik dan konkret. Perbedaan dan kebaruan yang lain adalah pada tahap memilih tema dilakukan pengembangan sub-sub tema yang dipadukan konteks sekitar sehingga sub-sub tema yang dikembangkan sesuai dengan latar lingkungan siswa. Pada tahap mengembangkan sub-sub tema dihasilkan produk berupa jaringan sub-sub tema. Langkah kedua melakukan analisis SKL, KI, KD dan membuat indikator, menghasilkan berupa tabel analisis SKL, KI, KD dan indikator. Langkah ketiga membuat hubungan pemetaan antara KD dan indikator menghasilkan tabel keterhubungan KD dan indikator. Langkah keempat membuat jaringan KD. Pada tahap ini selain mengembangkan jaringan KD juga mengembangkan jaringan indikator yang akhirnya menghasilkan produk jaringan $\mathrm{KD}$ dan indikator. Langkah kelima yaitu menyusun silabus, dan langkah terakhir menyusun RPP. Pada langkah penyusunan RPP terdapat tahap untuk mengembangkan materi, sehingga perlu dilakukan pengembangan materi. Materi yang dikembangkan dituangkan dalam penggalan buku guru dan buku siswa. 


\section{METODE}

Sesuai dengan tujuannya, penelitian ini menggunakan jenis penelitian dan pengembangan $(R \& D)$, dengan tahapan studi pendahuluan, desain dan pengembangan model, dan tahap pengujian model. Ketiga langkah tersebut merupakan penyederhanaan dari sepuluh langkah $R \& D$ dari Borg and Gall (Borg, Gall \& Gall, 2007: 589; Borg and Gall, 2003: 570; Sukmadinata, 2007: 184). Pada tahap studi pendahuluan dilakukan studi pustaka untuk mengumpulkan bahan-bahan pendukung. Khususnya berkaitan dengan: konsep/paradigma penelitian dan pengembangan, desain pembelajaran, serta konsep dan kebermaknaan belajar. Kemudian dilanjutkan dengan survei skala kecil. Sasaran survei skala kecil meliputi bagaimana model desain pembelajaran aktual (silabus dan RPP, buku guru, dan buku siswa), permasalahan yang muncul dalam mendesain dan melaksanakan pembelajaran, dan kebutuhan desain pembelajaran. Selanjutnya dikembangkan kerangka model desain pembelajaan tematik terpadu kontekstual yang terdiri dari rumusan kompetensi dan indikator yang akan dikembangkan, dan materi pembelajaran. Semua rancangan ini dituangkan dalam bentuk silabus dan RPP. Luaran kegiatan ini adalah kerangka model. Pada tahap desain dan pengembangan model, dilakukan pengembangan model awal yang telah dilengkapi silabus dan RPP, yang dituangkan dalam bentuk draft model. Draft model ini kemudian divalidasi ahli desain pembelajaran tematik terpadu dan ahli materi pembelajaran ke-SD-an. Instrumen uji validasi ahli menggunakan rubrik penilaian pakar. Luaran dari kegiatan ini adalah model valid secara konstruk dan isi. Target penilaian pakar berada pada kategori baik. Draft model yang telah divalidasi dan direvisi, selanjutnya dilakukan uji lapangan terbatas (preliminary field testing) melibatkan 4 guru dan 57 siswa SD serta uji lebih luas (main field testing) melibatkan 8 guru dan 94 siswa SD. Jenis pengujian menggunakan jenis penelitian preeksperimen dengan model one group pretest-postest design, dan uji statistik (uji t). Instrumen penelitian menggunakan soal tes untuk mengukur kebermaknaan belajar siswa. Sebagai catatan, tahap pengujian model sebagai tahap terakhir dalam penelitian ini dilakukan pada tahun anggaran berikutnya.

\section{HASIL PENELITIAN DAN PEMBAHASAN}

\section{Hasil Penelitian}

Hasil validasi model desain pembelajaran tematik terpadu kontekstual yang dilakukan oleh 2 orang ahli model desain pembelajaran dan ahli materi ke-SD-an dipaparkan dalam tabel 1, 2 dan 3.

Dari tabel 1 diperoleh data bahwa rata-rata skor penilaian ahli model desain pembelajaran pada model sebesar 15,5 (86\%). Di samping memberikan penilaian, para ahli juga memberikan saransaran dan menyatakan bahwa model desain pembelajaran ini dapat digunakan setelah dilakukan perbaikan sesuai saran. Berdasarkan kategori skor yang telah ditetapkan, skor yang diperoleh dikelompokkan ke dalam 5 kategori $(1 \%-20 \%=$ sangat rendah; $21 \%-40 \%=$ rendah; $41 \%-60 \%=$ cukup; $61 \%-80 \%=$ tinggi; dan $81 \%-100 \%=$ sangat tinggi), maka model tergolong kategori sangat tinggi berada pada interval $81 \%$ sampai $100 \%$.

Tabel 1. Hasil Validasi Ahli Model Desain Pembelajaran

\begin{tabular}{|c|c|c|c|}
\hline \multirow{2}{*}{ Desain } & \multirow{2}{*}{ Indikator } & \multicolumn{2}{|c|}{ Skor } \\
\hline & & Ahli 1 & Ahli 2 \\
\hline \multirow{6}{*}{ 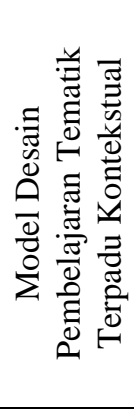 } & $\begin{array}{l}\text { 1. Menggambarkan kerangka konseptual desain pembelajaran } \\
\text { tematik terpadu kontekstual }\end{array}$ & 2 & 2 \\
\hline & 2. Mendeskripsikan konstruk, tujuan, dan langkah-langkah. & 3 & 2 \\
\hline & $\begin{array}{l}\text { 3. Menggunakan teori pendidikan dan teori belajar dari para } \\
\text { ahli }\end{array}$ & 2 & 3 \\
\hline & $\begin{array}{l}\text { 4. Menggambarkan tujuan desain pembelajaran tematik } \\
\text { terpadu yang jelas }\end{array}$ & 2 & 3 \\
\hline & $\begin{array}{l}\text { 5. Berisi langkah-langkah konkrit sebagai sebuah model } \\
\text { pembelajaran tematik terpadu }\end{array}$ & 3 & 3 \\
\hline & 6. Menunjukkan keterpaduan dengan konteks domisili siswa & 3 & 3 \\
\hline & Jumlah & 15 & 16 \\
\hline & Rerata skor & \multicolumn{2}{|c|}{15,5} \\
\hline
\end{tabular}

Keterangan: rentang skor 1 s.d 3, skor maksimal 18 (100\%) 
Walaupun model sudah termasuk dalam kategori sangat tinggi namun model masih perlu disempurnakan sesuai saran ahli desain pembelajaran sehingga dilakukan revisi dan perbaikan sebelum dilakukan uji coba terbatas. Adapun yang perlu diperbaiki menurut ahli 1 yaitu model perlu menonjolkan kekontekstualannya, panduan penyusunan RPP tematik perlu diuraian dengan jelas, teori perumusan tujuan pembelajaran harus lebih jelas, dan yang terakhir koding perlu diperbaiki.

Tabel 2. Hasil Validasi Ahli Desain Pembelajaran (Silabus dan RPP)

\begin{tabular}{|c|c|c|c|}
\hline \multirow{2}{*}{ Desain } & \multirow{2}{*}{ Indikator } & \multicolumn{2}{|c|}{ Skor } \\
\hline & & Ahli 1 & Ahli 2 \\
\hline \multirow{7}{*}{$\frac{\text { 气 }}{\frac{0}{\tilde{a}}}$} & 1. Memuat seluruh komponen pembelajaran & 2 & 2 \\
\hline & 2. Relevansi antar komponen pembelajaran & 2 & 2 \\
\hline & 3. Kesesuaian silabus dengan KD, Indikator dan sub-sub tema & 2 & 2 \\
\hline & 4. Kualitas perumusan indikator & 2 & 2 \\
\hline & 5. Relevansi indikator terhadap KD & 2 & 2 \\
\hline & 6. Kesesuaian KD dengan pembelajaran & 2 & 2 \\
\hline & 7. Kualitas pemilihan kegiatan pembelajaran & 3 & 2 \\
\hline \multirow{9}{*}{$\hat{\bar{a}}$} & 1. Memuat seluruh komponen KD & 2 & 2 \\
\hline & 2. Komponen-komponen saling berkaitan & 2 & 2 \\
\hline & 3. Kejelasan perumusan tujuan dengan indikator & 2 & 2 \\
\hline & 4. Kelengkapan materi & 2 & 2 \\
\hline & 5. Keruntutan skenario pembelajaran & 2 & 2 \\
\hline & $\begin{array}{l}\text { 6. Ketepatan memilih strategi interaksi sehingga memperkaya } \\
\text { pengalaman belajar }\end{array}$ & 2 & 3 \\
\hline & 7. Ketepatan memilih alat,media dan sumber belajar & 2 & 2 \\
\hline & 8. Kesesuaian dengan alokasi waktu pembelajaran & 2 & 2 \\
\hline & 9. Kesesuaian instrumen asesmen dengan indikator & 2 & 3 \\
\hline & Jumlah & 33 & 34 \\
\hline & Rerata & \multicolumn{2}{|c|}{33,5} \\
\hline
\end{tabular}

Keterangan: rentang skor 1 s.d 3, skor maksimal 48 (100\%)

Dari tabel 2 diperoleh data bahwa rata-rata skor penilaian ahli desain pembelajaran berupa Silabus dan RPP sebesar 33,5 (69,8\%). Di samping memberikan penilaian, para ahli juga memberikan saran-saran dan menyatakan bahwa model desain pembelajaran ini dapat digunakan setelah dilakukan perbaikan sesuai saran. Berdasarkan 5 kategori yang ditetapkan $(1 \%-20 \%=$ sangat rendah; $21 \%$ $40 \%=$ rendah; $41 \%-60 \%=$ cukup; $61 \%-80 \%=$ tinggi; dan $81 \%-100 \%=$ sangat tinggi), maka desain pembelajaran berupa Silabus dan RPP berada pada kategori tinggi, diantara interval $61 \%$ sampai $80 \%$. Walaupun desain sudah termasuk dalam kategori tinggi namun Silabus dan RPP masih perlu disempurnakan sesuai saran ahli desain pembelajaran sehingga dilakukan revisi dan perbaikan sebelum dilakukan uji coba terbatas. Adapun yang perlu diperbaiki menurut ahli 1 dan 2 yaitu yaitu pada skenario proses belajar mengajar yang belum terdapat EEK, penilaian pada silabus belum lengkap, dan perlu menambahkan gambar pada RPP agar lebih menarik.

Penilaian kelayakan materi ke-SD-an meliputi aspek kesesuaian materi dengan kurikulum SD yang berlaku; kesesuaian indikator dengan materi; kesesuaian materi terhadap lingkungan peserta didik; kelengkapan materi; keterpaduan materi; kesesuaian materi dengan alokasi waktu yang tersedia; kejelasan bahasa yang digunakan; kejelasan informasi pada ilustrasi gambar; keruntutan penyajian materi; kemenarikan tampilan; kesesuaian latihan soal dengan materi; dan kebakuan istilah. Tabel 3 berikut merupakan hasil penilaian desain materi ke-SD-an oleh ahli materi.

Tabel 3. Hasil Penilaian Kelayakan Materi Oleh Ahli Materi Ke-SD-an

\begin{tabular}{|c|c|c|c|}
\hline \multirow{2}{*}{ Aspek } & \multirow{2}{*}{ Indikator } & \multicolumn{2}{|c|}{ Skor } \\
\hline & & Ahli 1 & Ahli 2 \\
\hline \multirow{4}{*}{ 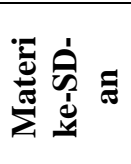 } & 1.Kesesuaian materi dengan kurikulum SD yang berlaku & 2 & 2 \\
\hline & 2. Kesesuaian indikator dengan materi & 2 & 2 \\
\hline & 3.Kesesuaian materi terhadap lingkungan peserta didik & 2 & 2 \\
\hline & 4.Kelengkapan materi & 3 & 3 \\
\hline
\end{tabular}




\begin{tabular}{lcc}
\hline 5.Keterpaduan materi & 3 & 2 \\
\hline 6.Kesesuaian materi dengan alokasi waktu yang tersedia & 2 & 2 \\
\hline 7.Kejelasan bahasa yang digunakan & 2 & 2 \\
\hline 8.Kejelasan informasi pada ilustrasi gambar & 1 & 1 \\
\hline 9.Keruntutan penyajian materi & 2 & 2 \\
\hline 10. Kemenarikan tampilan & 3 & 2 \\
\hline 11. Kesesuaian latihan soal dengan materi & 3 & 2 \\
\hline 12. Kebakuan istilah & 2 & 2 \\
\hline & 27 & 23 \\
\hline
\end{tabular}

Keterangan: rentang skor 1 s.d 3, skor maksimal 36 (100\%)

Data pada tabel 3 tersebut di atas, setelah dilakukan analisis, diperoleh rata-rata skor penilaian ahli materi sebesar $25(69 \%)$. Berdasarkan 5 kategori yang ditetapkan $(1 \%-20 \%=$ sangat rendah; $21 \%-40 \%=$ rendah; $41 \%-60 \%=$ cukup; $61 \%-80 \%=$ tinggi; dan $81 \%-100 \%=$ sangat tinggi), maka desain materi berada pada kategori tinggi, terletak diantara interval $61 \%$ sampai $80 \%$. Walaupun desain sudah termasuk dalam kategori tinggi namun masih perlu disempurnakan. Adapun yang perlu diperbaiki menurut ahli materi adalah pada penambahan gambar pada cerita dan perlu menggunakan resolusi tinggi pada gambar dan perlu layout yang menarik.

Uji lapangan terbatas seperti telah dipaparkan melibatkan 4 guru SD di Salatiga dan 60 siswa, namun 3 orang siswa berhalangan hadir ketika uji lapangan ini dilaksanakan, sehingga jumlah siswa yang dilibatkan berkurang 3 menjadi 57 siswa. Jenis pengujian menggunakan jenis penelitian preeksperimen dengan model one group pretest-postest design. Proses pembelajaran di kelas dilakukan oleh guru kelas dan berpedoman pada RPP yang telah disusun. Terdiri dari kegiatan awal, kegiatan inti dan kegiatan akhir. Pada kegiatan awal dilakukan apersepsi dan motivasi serta diakhiri dengan pemberian pretes. Pada kegiatan inti dilakukan serangkaian kegiatan pembelajaran menggunakan Buku Siswa yang telah dikembangkan oleh peneliti. Kegiatan pembelajaran dikaitkan dengan lingkungan peserta didik dan sub-sub tema yang dikembangkan, yaitu Petani. Kegiatan inti diakhiri dengan bermain peran Petani yang mengajak siswa untuk kegiatan ke lahan pertanian. Pada kegiatan akhir dilakukan penyimpulan bersama siswa dan guru, tanya jawab apakah tujuan tercapai dan diakhiri dengan postes. Postes dilakukan untuk melihat apakah pembelajaran dapat diterima dan dipahami siswa. Berkaitan dengan data hasil uji lapangan terbatas dengan menerapkan model desain pembelajaran tematik terpadu, ditemukan data statistik deskriptif dan distribusi frekuensi seperti terangkum dalam tabel 5 , dan 6 berikut.

Tabel 5. Statistik Deskriptif Hasil Pretes dan Postes Siswa Kelas 4 SD pada Uji Coba Lapangan Terbatas Descriptive Statistics

\begin{tabular}{llrrrr}
\hline & $\boldsymbol{N}$ & Minimum & Maximum & Mean & Std. Deviation \\
\hline pretesujiterbatas & 57 & 13 & 78 & 49,49 & 17,876 \\
postesujiterbatas & 57 & 14 & 93 & 69,44 & 18,048 \\
\hline Valid N (listwise) & 57 & & & & \\
\hline
\end{tabular}

Tabel 5 memberikan informasi bahwa rerata pretes siswa mencapai 49,49, bergerak antara 13 sampai 78; sedangkan rerata hasil pengukuran postes sebagai cerminan kebermaknaan belajar mereka mencapai 69,44, bergerak antara 14 sampai 93. Standar deviasi pada pretes 17,876, sedangkan SD pada postes adalah 18,048. Tabel 6 memberikan informasi bahwa ada kenaikan skor kebermaknaan siswa. Data hasil pretes menunjukkan temuan ada 4 siswa $(7,02 \%)$ memperoleh skor $\leq 19$ berada pada kategori sangat rendah; 15 orang siswa $(26,32 \%)$ memperoleh skor antara 20-39, berada pada kategori rendah; 19 orang $(33,33 \%)$ memperoleh skor 40-59, berada pada kategori cukup; 19 orang (33,33\%) memperoleh skor antara 60-79, berada pada kategori tinggi dan tak seorang siswapun memperoleh skor $\geq 80$. Dilihat dari penyebaran skornya, nampak bahwa baik pretes maupun postes terdistribusi secara normal dan data homogen. 
Model Desain Pembelajaran Tematik Terpadu Kontekstual Untuk Meningkatkan Kebermaknaan Belajar Siswa SD (Mawardi, Naniek S. Wardani, Agustina T. A. Hardini, Firosalia Kristin)

Tabel 6. Distribusi Frekuensi Kebermaknaan Belajar Siswa Kelas 4 SD pada Uji Coba Lapangan Terbatas

\begin{tabular}{|c|c|c|c|c|c|c|}
\hline \multirow{3}{*}{ No. } & \multirow{3}{*}{ Kategori } & \multirow{3}{*}{ Interval skor } & \multicolumn{4}{|c|}{ Keberkmaknaan Belajar } \\
\hline & & & \multicolumn{2}{|c|}{ Pretes } & \multicolumn{2}{|c|}{ Postes } \\
\hline & & & $\mathbf{f}$ & $\%$ & f & $\%$ \\
\hline 1 & Sangat Tinggi & $\geq 80$ & 0 & 0 & 18 & 31,58 \\
\hline 2 & Tinggi & $60-79$ & 19 & 33,33 & 30 & 52,63 \\
\hline 3 & Cukup & $40-59$ & 19 & 33,33 & 5 & 8,77 \\
\hline 4 & Rendah & $20-39$ & 15 & 26,32 & 0 & 0,00 \\
\hline \multirow[t]{2}{*}{5} & Sangat Rendah & $\leq 19$ & 4 & 7,02 & 4 & 7,02 \\
\hline & & Total & 57 & 100 & 57 & 100 \\
\hline
\end{tabular}

Pada pengukuran postes, tabel 6 memberikan informasi bahwa ada 4 siswa $(7,02 \%)$ memperoleh skor $\leq 19$ berada pada kategori sangat rendah; 5 orang siswa $(8,77 \%)$ memperoleh skor antara 40-59, berada pada kategori cukup; 30 orang $(52,63 \%)$ memperoleh skor antara 60-79, berada pada kategori tinggi dan 18 orang siswa $(31,58 \%)$. Untuk mengetahui seberapa dampak perlakuan terhadap kebermaknaan belajar siswa setelah diterapkan model desain pembelajaran tematik terpadu kontekstual dilakukan penelitian pre-eksperimen dengan menggunakan uji t. Sebagaimana diketahui secara umum bahwa persyaratan uji statistik uji t adalah data terdistribusi normal dan varian homogen, maka uji t dapat dilakukan. Tabel 7 berikut merangkum hasil uji t terhadap hasil pretes dan postes siswa kelas 4 SD yang dilibatkan dalam penelitian.

Tabel 7. Hasil Uji t Terhadap Hasil Pretes dan Postes Siswa

Paired Sample Test

\begin{tabular}{|c|c|c|c|c|c|c|c|c|c|}
\hline & & \multicolumn{5}{|c|}{ Paired Differences } & \multirow[b]{3}{*}{$\mathbf{t}$} & \multirow[b]{3}{*}{ df } & \multirow[b]{3}{*}{ Sig. (2-tailed) } \\
\hline & & \multirow[b]{2}{*}{ Mean } & \multicolumn{4}{|c|}{$\begin{array}{l}\text { 95\% Confidence Interval } \\
\text { Std. Error } \quad \text { of the Difference }\end{array}$} & & & \\
\hline & & & Std. Deviation & Mean & Lower & Upper & & & \\
\hline $\begin{array}{c}\text { Pair } \\
1\end{array}$ & $\begin{array}{l}\text { pretestujiterbatas- } \\
\text { postestujiterbatas }\end{array}$ & $-19,947$ & 13,652 & 1,808 & $-23,570$ & $-16,325$ & $-11,031$ & 56 & ,000 \\
\hline
\end{tabular}

Dari tabel 7 di atas, nampak bahwa nilai t tabel sebesar -11,031 dengan nilai probabilitas 0,000. Sesuai nilai default SPSS pengujian dilakukan dengan taraf kepercayaan 0,05 maka diperoleh hasil bahwa nilai probabilitas lebih kecil dari $\alpha=0,05$. Jika dirumuskan hipotesis $H_{0}$ : Rerata kebermaknaan belajar siswa kelas 4 SD pada pretes tidak berbeda secara signifikan dengan kebermaknaan belajar siswa kelas 4 SD pada postes, maka hipotesis ini ditolak dan diterima $\mathrm{H}_{\mathrm{a}}$ yang menyatakan bahwa berata kebermaknaan belajar siswa kelas 4 SD pada pretes berbeda secara signifikan dengan kebermaknaan belajar siswa kelas 4 SD pada postes karena nilai probabilitas 0,000 lebih kecil dari nilai $\alpha=0,05$. Artinya terdapat perbedaan kebermaknaan belajar siswa kelas $4 \mathrm{SD}$ sebelum dan sesudah menerima pembelajaran dengan menerapkan desain pembelajaran tematik terpadu kontekstual.

Uji lapangan luas seperti telah dipaparkan melibatkan 8 guru dan 94 siswa. Sama halnya uji lapangan terbatas, jenis pengujian menggunakan jenis penelitian pre-eksperimen dengan model one group pretest-postest design. Proses pembelajaran di kelas dilakukan oleh guru kelas dan berpedoman pada RPP yang telah disusun. Terdiri dari kegiatan awal, kegiatan inti dan kegiatan akhir. Pada kegiatan awal dilakukan apersepsi dan motivasi serta diakhiri dengan pemberian pretes. Pada kegiatan inti dilakukan serangkaian kegiatan pembelajaran menggunakan penggalan materi yang telah dikembangkan oleh peneliti. Kegiatan pembelajaran dikaitkan dengan lingkungan peserta didik dan sub-sub tema yang dikembangkan, yaitu Petani. Kegiatan inti diakhiri dengan bermain peran Petani yang mengajak siswa untuk kegiatan ke lahan pertanian. Pada kegiatan akhir dilakukan penyimpulan bersama siswa dan guru, pemberian reward, tanya jawab tujuan yang diperoleh setelah belajar bagaimana para petani bekerja dan diakhiri dengan pemberian postes. Postes dilakukan untuk melihat apakah pembelajaran dapat diterima dan dipahami siswa. Postes juga digunakan untuk mengukur pembelajaran kontekstual berhasil atau tidak. 
Berkaitan dengan data hasil uji lapangan luas dengan menerapkan model desain pembelajaran tematik terpadu kontekstual dengan menambahkan sub-subtema Petani, ditemukan data statistik deskriptif dan distribusi frekuensi seperti terangkum dalam tabel 8, dan 9 berikut.

Tabel 8. Statistik Deskriptif Hasil Pretes dan Postes Siswa Kelas 4 SD pada Uji Coba Lapangan Luas Descriptive Statistics

\begin{tabular}{lrrrrr}
\hline & $\boldsymbol{N}$ & Minimum & Maximum & Mean & Std. Deviation \\
\hline pretesujiluas & 94 & 22 & 80 & 47,98 & 15,280 \\
postesujiluas & 94 & 29 & 96 & 70,43 & 13,199 \\
\hline Valid N (listwise) & 94 & & & & \\
\hline
\end{tabular}

Tabel 8 memberikan informasi bahwa rerata pretes siswa mencapai 47,98, bergerak antara 22 sampai 80; sedangkan rerata hasil pengukuran postes sebagai cerminan kebermaknaan belajar pada uji coba lapangan luas mencapai 70,43, bergerak antara 29 sampai 96. Standar deviasi pada pretes 15,280, sedangkan SD pada postes adalah 13,199. Tabel 9 memberikan informasi bahwa ada kenaikan skor kebermaknaan siswa. Data hasil pretes menunjukkan temuan tidak ada siswa yang memperoleh skor $\leq 19$; ada 32 orang siswa $(34,043 \%)$ memperoleh skor antara 20-39, berada pada kategori rendah; ada 37 orang $(39,362 \%)$ memperoleh skor $40-59$, berada pada kategori cukup; ada 24 orang $(25,531 \%)$ memperoleh skor antara $60-79$, berada pada kategori tinggi dan 1 orang siswa $(1,064 \%)$ memperoleh skor $\geq 80$, berada pada kategori sangat tinggi. Dilihat dari penyebaran skornya, nampak bahwa baik pretes maupun postes terdistribusi secara normal dan data homogen.

Tabel 9. Distribusi Frekuensi Kebermaknaan Belajar Siswa Kelas 4 SD pada Uji Coba Lapang Luas

\begin{tabular}{rccrrrr}
\hline \multirow{2}{*}{ No. } & \multirow{2}{*}{ Kategori } & \multirow{2}{*}{ Interval skor } & \multicolumn{3}{c}{ Keberkmaknaan Belajar } \\
\cline { 3 - 7 } & & & \multicolumn{2}{c}{ Pretes } & \multicolumn{2}{c}{ Postes } \\
\cline { 3 - 7 } & & $\mathbf{f}$ & \multicolumn{1}{c}{$\%$} & f & \multicolumn{1}{c}{$\%$} \\
\hline 1 & Sangat Tinggi & $\geq 80$ & 1 & 1,064 & 19 & 20,212 \\
\hline 2 & Tinggi & $60-79$ & 24 & 25,531 & 64 & 68,085 \\
\hline 3 & Cukup & $40-59$ & 37 & 39,362 & 6 & 6,383 \\
\hline 4 & Rendah & $20-39$ & 32 & 34,043 & 5 & 5,320 \\
\hline 5 & Sangat Rendah & $\leq 19$ & 0 & 0 & 0 & 0 \\
\hline & & Total & 94 & 100 & 94 & 100 \\
\hline
\end{tabular}

Pada pengukuran postes, tabel 9 memberikan informasi bahwa tidak ada siswa yang memperoleh skor $\leq 19$ berada pada kategori sangat rendah; 5 orang siswa $(5,320 \%)$ memperoleh skor antara 20 - 39, berada pada kategori rendah; ada 6 siswa (6,383\%) memperoleh skor antara 40-59, berada pada kategori cukup; 64 orang siswa $(68,085 \%)$ memperoleh skor antara 60-79, berada pada kategori tinggi dan 19 orang siswa $(20,212 \%)$ memperoleh skor $\geq 80$ berada pada kategori sangat tinggi. Seperti halnya deskripsi uji coba lapangan terbatas, untuk mengetahui perbedaan hasil perlakuan terhadap kebermaknaan belajar siswa setelah diterapkan model desain pembelajaran tematik terpadu kontekstual dilakukan penelitian pre-eksperimen dengan menggunakan uji t. Senada dengan deskripsi pada uji lapangan terbatas, telah diketahui secara umum bahwa persyaratan uji t adalah data terdistribusi normal dan varian homogen, maka uji t dapat dilakukan. Tabel 10 berikut merangkum hasil uji t terhadap hasil pretes dan postes siswa kelas 4 SD yang dilibatkan dalam uji coba lapangan luas.

Tabel 10. Hasil Uji t terhadap Hasil Pretes dan Postes Siswa Pada Uji Lapang Luas Paired Sample Test

\begin{tabular}{|c|c|c|c|c|c|c|c|c|c|}
\hline & & \multicolumn{5}{|c|}{ Paired Differences } & \multirow[b]{3}{*}{$\mathbf{t}$} & \multirow[b]{3}{*}{ df } & \multirow[b]{3}{*}{ Sig. (2-tailed) } \\
\hline & & \multirow[b]{2}{*}{ Mean } & \multicolumn{4}{|c|}{$95 \%$ Confidence Interval } & & & \\
\hline & & & Std. Deviation & Mean & Lower & Upper & & & \\
\hline $\begin{array}{c}\text { Pair } \\
1\end{array}$ & $\begin{array}{l}\text { pretestujiluas- } \\
\text { postestujiluas }\end{array}$ & $-22,447$ & 12,565 & 1,296 & $-25,020$ & $-19,873$ & $-17,320$ & 93 & 000 \\
\hline
\end{tabular}


Dari tabel 10 di atas, nampak bahwa nilai t tabel sebesar -17,320 dengan nilai probabilitas 0,000. Sesuai nilai default SPSS pengujian dilakukan dengan taraf kepercayaan 0,05 maka diperoleh hasil bahwa nilai probabilitas lebih kecil dari $\alpha=0,05$. Jika dirumuskan hipotesis $H_{0}$ : Rerata kebermaknaan belajar siswa kelas 4 SD pada pretes tidak berbeda secara signifikan dengan kebermaknaan belajar siswa kelas 4 SD pada postes, maka hipotesis ini ditolak dan diterima $\mathrm{H}_{\mathrm{a}}$ yang menyatakan bahwa rerata kebermaknaan belajar siswa kelas 4 SD pada pretes berbeda secara signifikan dengan kebermaknaan belajar siswa kelas 4 SD pada postes karena nilai probabilitas 0,000 lebih kecil dari nilai $\alpha=0,05$. Artinya terdapat perbedaan kebermaknaan belajar siswa kelas $4 \mathrm{SD}$ sebelum dan sesudah menerima pembelajaran dengan menerapkan desain pembelajaran tematik terpadu kontekstual.

Pembahasan

Seperti telah dideskripsikan pada bagian pendahuluan, penelitian ini bertujuan untuk mengembangkan model desain pembelajaran tematik terpadu kontekstual, mengetahui seberapa tinggi tingkat validitas produk modelnya, dan mengetahui apakah kebermaknaan belajar siswa dapat ditingkatkan menggunakan model desain tematik terpadu kontekstual tersebut. Dalam mengembangkan model desain pembelajaran tematik terpadu kontekstual, langkah pertama adalah memilih tema. Pada tahap memilih tema, agar seting pembelajaran sesuai dengan domiisili siswa, maka ditambahkan sub-subtema. Pada penelitian ini peneliti memilih Tema 4 kelas 4 Berbagai Pekerjaan Sub tema 1 jenis-jenis pekerjaan. Sub-subtema yang ditambahkan adalah Petani, karena lingkungan domisili siswa umumnya para petani. Langkah kedua melakukan analisis SKL, KI, KD dan membuat Indikator menghasilkan produk berupa tabel analisis SKL, KI, KD dan membuat Indikator. Langkah ketiga membuat hubungan pemetaan antara KD dan indikator menghasilkan tabel keterhubungan KD dan indikator. Langkah keempat membuat jaringan KD. Pada tahap ini selain mengembangkan jaringan KD juga mengembangkan jaringan indikator yang akhirnya menghasilkan produk jaringan KD dan Indikator. Langkah kelima yaitu menyusun silabus yang menghasilkan silabus, dan langkah terakhir menyusun RPP yang menghasilkan RPP. Pada langkah penyusunan RPP disusun juga penggalan buku guru dan buku siswa.

Hasil penelitian pada tahap pengembangan model menemukan data bahwa tingkat validitas model desain pembelajaran tematik terpadu berada pada kategori sangat tinggi (86\%), Silabus dan RPP berada pada kategori tinggi $(69,8 \%)$; sedangkan validitas materi pembelajaran berada pada kategori tinggi (69\%). Keberhasilan mengembangkan model desain pemebelajaran tematik terpadu kontekstual sehingga mencapai kategori baik dan sangat baik oleh karena penambahan sub-sub tema "Petani" sebagai seting pembelajaran. Sub-sub tema Petani relevan dengan tema dan sub tema tentang jenis-jenis pekerjaan, penambahan ini sesuai juga dengan kebanyakan matapencaharian masyarakat di sekitar domisili siswa. Secara teoretik, keberhasilan dalam mengembangkan model desain pembelajaran ini sejalan dengan pandangan Hosnan (2014: 366), yang menyatakan bahwa jaring tema sebaiknya disesuaikan dengan lingkungan siswa agar pembelajaran bermakna bagi mereka. Pandangan ini juga sejalan dengan pernyataan bahwa penggunaan tema sekitar siswa untuk mengaitkan beberapa matapelajaran dapat memberikan pengalaman bermakna pada siswa (Kemendikbud, 2014: 16). Temuan ini juga sejalan dengan penelitian yang menemukan bahwa penambahan sub-subtema dengan jenis pekerjaan yang terdapat di lingkungan siswa merupakan desain pembelajaran yang dinilai baik oleh para ahli desain pembelajaran (Pringgondani, 2016)

Hasil uji lapangan terbatas maupun uji luas menemukan bahwa kebermaknaan belajar siswa meningkat. Peningkatan ini signifikan oleh karena pada uji t diketahui bahwa nilai t tabel sebesar 11,031 dengan nilai probabilitas 0,000 . Sesuai nilai default SPSS pengujian dilakukan dengan taraf kepercayaan 0,05 maka diperoleh hasil bahwa nilai probabilitas lebih kecil dari $\alpha=0,05$. Jika dirumuskan hipotesis $\mathrm{H}_{0}$ : Rerata kebermaknaan belajar siswa kelas 4 SD pada pretes tidak berbeda secara signifikan dengan kebermaknaan belajar siswa kelas 4 SD pada postes, maka hipotesis ini ditolak dan diterima $\mathrm{H}_{\mathrm{a}}$ yang menyatakan bahwa berata kebermaknaan belajar siswa kelas 4 SD pada pretes berbeda secara signifikan dengan kebermaknaan belajar siswa kelas 4 SD pada postes karena nilai probabilitas 0,000 lebih kecil dari nilai $\alpha=0,05$. Artinya terdapat perbedaan kebermaknaan belajar siswa kelas 4 SD sebelum dan sesudah menerima pembelajaran dengan menerapkan desain pembelajaran tematik terpadu kontekstual. Temuan penelitian pada saat uji lapangan terbatas maupun luas yang menyatakan bahwa ada peningkatan kebermaknaan beajar ini merupakan pembuktian dari 
pernyataan bahwa penggunaan tema sekitar siswa untuk mengaitkan beberapa matapelajaran dapat memberikan pengalaman bermakna pada siswa (Kemendikbud, 2014: 16).

Temuan bahwa penerapan model desain pembelajaran tematik terpadu kontekstual dapat meningkatkan kebermaknaan belajar siswa juga sejalan dengan penelitian Asep Herry Hermawan (2015) yang meneliti tentang pengembangan model pembelajaran tematik di kelas awal siswa SD menunjukan bahwa model mampu meningkatkan hasil belajar dan layak digunakan dalam pembelajaran. Demikian juga penelitian Isniatun Munawaroh (2014) yang meneliti tentang Pengembangan Model Pembelajaran Tematik untuk Mengembangkan Keterampilan Berpikir Kritis siswa SD Kelas Rendah, hasilnya menunjukkan bahwa tingkat validitas model cukup valid dengan tingkat persentase $95 \%$, dilihat dari kenaikan skor nilai pre-test terhadap skor nilai post-test cukup signifikan; Simpulannya, hasil tersebut membuktikan bahwa model pembelajaran tematik telah valid dan layak digunakan dalam pembelajaran.

Penelitian lain yang sejalan dengan temuan ini adalah penelitian Jamaluddin (2015) meneliti tentang Pengembangan Model Pembelajaran Tematik Terpadu Kontekstual bagi Anak Usia Dini di Taman Kanak-Kanak Kelompok B. Hasil menunjukan tingkat keefektifan mencapai presentase $\geq 90 \%$ dan guru memberikan respon yang positif. Hasil tersebut menyatakan bahwa model pembelajaran tematik layak digunakan dalam pembelajaran. Demikian juga penelitian Fatchurrohman (2015) yang meneliti tentang Pengembangan Model Pembelajaran Tematik Integratif Eksternal dan Internal di Madrasah Ibtidaiyah. Hasil menunjukan guru nyaman dan cocok terhadap model yang dikembangkan dan hasil evaluasi yang baik. Sehingga hasil tersebut menyatakan bahwa model pembelajaran tematik layak digunakan dalam pembelajaran.

Penelitian lain yang sejalan dengan temuan penelitian ini, meskipun berbeda jenis penelitiannya adalah penelitian tindakan yang dilakukan oleh Julianti \& Mawardi (2018) serta penelitian Kharisma \& Mawardi (2018). Penelitian Julianti \& Mawardi tentang peningkatan kebermaknaan belajar dan hasil belajar siswa dengan menerapkan desain pembelajaran tematik integratif berbasis sub-subtema menemukan adanya peningkatan persentase jumlah siswa yang mencapai kategori bermakna dan sangat bermakna, sedangkan penelitian Kharisma \& Mawardi tentang Implementation of an environmental-based alternative integrative thematic model to increase meaningfulness and learning outcome, menemukan hasil bahwa penerapan model pembelajaran tematik terpadu berbasis lingkungan dapat meningkatkan bekermaknaan dan hasil belajar siswa.

Berdasarkan temuan penelitian ini dan berbagai penelitian terdahulu, meskipun model desain pembelajaran tematik terpadu kontekstual diterima oleh guru dan layak digunakan, namun dari berbagai penelitian terdahulu belum ada yang menggunakan uji $\mathrm{t}$ dalam melihat perbedaan kompetensi hasil belajar siswa. Sehingga penelitian ini memberikan kontribusi data empirik perbedaan dampak kebermaknaan belajar siswa dengan menggunakan Model Desain Pembelajaran Tematik terpadu kontekstual dengan Model Desain Pembelajaran Tematik Terpadu dari Kemendikbud. Dengan demikian model desain pembelajaran ini layak digunakan dalam pembelajaran di kelas rendah maupun dikelas tinggi, sehingga dapat dikatakan model desain pembelajaran tematik integratif berbasis lingkungan memang tepat diterapkan dalam pembelajaran di Sekolah Dasar. Sebagai cacatan akhir, model desain pembelajaran tematik terpadu ini masih perlu dilakukan pengujian keefktifannya agar memperoleh legitimasi yang lebih kuat.

\section{SIMPULAN DAN SARAN}

Berdasarkan hasil penelitian dan pembahasan, dapat ditarik kesimpulan berikut: a) langkahlangkah model desain pembelajaran tematik terpadu kontekstual mencakup: 1) menetapkan tema; 2) menambahkan sub-sub tema; 3) melakukan analisis SKL, KI, KD dan membuat indikator; 4) membuat hubungan pemetaan antara KD dan indikator dengan sub-subtema; 5) mengembangkan silabus; serta 6) mengembangkan RPP yang dilengkapi penggalan buku guru dan buku siswa; b) tingkat validitas model desain pembelajaran tematik terpadu berada pada kategori sangat tinggi (86\%), Silabus dan RPP berada pada kategori tinggi $(69,8 \%)$; sedangkan validitas materi pembelajaran berada pada kategori tinggi $(69 \%)$; c) berdasarkan hasil uji coba lapangan terbatas dan luas kebermaknaan belajar siswa mengalami peningkatan. Rerata tingkat kebermaknaan belajar siswa pada uji lapangan terbatas meningkat dari 49,49 pada pretes menjadi 69,44 pada saat dilakukan postes. Pada Uji lapangan luas peningkatan kebermaknaan belajar siswa meningkat lebih besar dari 
Model Desain Pembelajaran Tematik Terpadu Kontekstual Untuk Meningkatkan Kebermaknaan Belajar Siswa SD (Mawardi, Naniek S. Wardani, Agustina T. A. Hardini, Firosalia Kristin)

47,98 pada saaat dilakukan pretes menjadi 70,43 pada saat postes. Uji statistik menggunakan uji t memastikan bahwa peningkatan tersebut signifikan, karena nilai probabilitas $(0,00)$ lebih kecil dari nilai $\alpha=0,05$.

Berdasarkan simpulan hasil penelitian dan pengembangan model desain pembelajaran tematik terpadu kontekstual di atas, maka disarankan para guru mengembangkan sendiri pembelajannya agar pemahaman siswa lebih bermakna. Bagi peneliti lain, model desain pembelajaran tematik terpadu kontekstual dapat digunakan sebagai acuan dalam mendesain pembelajaran.

\section{UCAPAN TERIMAKASIH}

Ucapan terimakasih disampaikan kepada Universitas Kristen Satya Wacana yang telah mendanai penelitian ini melalui skema hibah internal penelitian terapan.

\section{DAFTAR PUSTAKA}

Ardiani, N. F. W., Guna, N. A., \& Novitasari, R. (2013). Pembelajaran Tematik dan Bermakna Dalam Perspektif Revisi Taksonomi Bloom. Jurnal Satya Widya, 29(2), 93-107.

Arifin, S. (2016). Pengaruh Pembelajaran Tematik-Integratif Berbasis Sosiokultural Terhadap Hasil Belajar Peserta Didik Kelas Iii Di Sekolah Dasar. Jurnal Profesi Pendidikan Dasar, 3(1), $16-$ 25.

Borg, Walter R. and Gall, Meredith D. (2003). Educational research. New York: Pearson.

Borg, Walter R., Gall, P.,Joyce, and Gall, Meredith D. (2007). Educational research. An introduction. Eighth edition.New York: Pearson.

Fatchurrohman. (2015). Pengembangan Model Pembelajaran Tematik Integratif Eksternal dan Internal di Madrasah Ibtidaiyah. Jurnal IAIN Salatiga. 2 (2), 1-15.

Fogarty, R. (2009). How to Integrate the Curricula, Third Edition. California: CORWIN, A Sage Company.

Hermawan. Asep. (2015). Pengembangan Model Pembelajaran Tematik di Kelas Awal Sekolah Dasar. Jurnal Universitas Pendidikan Indonesia. 2 (1), 1-14.

Hosnan. (2014). Pendekatan Saintifik dan Kontekstual dalam Pembelajaran Abad 21. Bogor: Ghalia Indonesia.

Jamaluddin. (2015). Pengembangan Model Pembelajaran Tematik Terpadu Kontekstual bagi Anak Usia Dini di Taman Kanak-Kanak Kelompok B. Tersedia di http://www.academia.edu.

Joyoatmodjo, Soetarno. (2011). Pembelajaran efektif, pembelajaran yang membelajarkan. Surakarta : Universitas Sebelas Maret Press.

John,Y.J. (2015). A "New" Thematic, Integrated Curriculum for Primary Schools of Trinidad and Tobago: A Paradigm Shift. International Journal of Higher Education 4 (3),172 - 187.

Julianti, I. A. R., \& Mawardi, M. (2018). Penerapan Desain Pembelajaran Tematik Integratif Alternatif Berbasis Sub-subtema untuk Meningkatkan Kebermaknaan dan Hasil Belajar. Jurnal Publikasi Pendidikan, 8(3), 206-215.

Kemendikbud. (2013). Permendikbud No.81A tentang Implementasi Kurikulum. Jakarta: Kementerian Pendidikan dan Kebudayaan.

Kharisma, Istna \& Mawardi. (2018). Implementation of an environmental-based alternative integrative thematic model to increase meaningfulness and learning outcome. Jurnal Pendidikan dan Pengajaran,51 (3), 154-162

Kim, M. K., \& Cho, M. K. (2015). Design and Implementation of Integrated Instruction of Mathematics and Science in Korea. Eurasia Journal of Mathematics, Science \& Technology Education, 11(1), 3-15. 
Koh, J.H.L. (2017). Designing and integrating reusable learning objects for meaningful learning: Cases from a graduate programme. Australasian Journal of Educational Technology, 33(5), $136-151$.

-.(2014). Materi Pelatihan Guru Implementasi Kurikulum 2013. Jakarta: Badan Pengembangan Sumber Daya Manusia Pendidikan dan Kebudayaan dan Penjaminan Mutu Pendidikan.

Rini, R., \& Mawardi, M. (2015). Peningkatan Keterampilan Proses Saintifik dan Hasil Belajar Siswa Kelas 4 SDN Slungkep 02 Tema Peduli Terhadap Makhluk Hidup Menggunakan Model Problem Based Learning. Scholaria: Jurnal Pendidikan dan Kebudayaan, 5(1), 103-113.

Munawaroh, I. (2010). Pengembangan Model Pembelajaran Tematik Untuk Mengembangkan Keterampilan Berpikir Kritis Siswa SD Kelas Rendah. Jurnal Penelitian Ilmu Pendidikan $U N Y, 3(1), 1-20$

Pringgondani, A.T.W. (2016). Pengembangan Model Desain Pembelajaran Tematik Integratif berbasis Lingkungan (Skripsi, Pendidikan Guru Sekolah Dasar - FKIP - UKSW)

Prastowo, A. (2014). Pengembangan Bahan Ajar Tematik. Yogyakarta: Diva Press.

Prastowo, A. (2014). Pemenuhan Kebutuhan Psikologis Peserta Didik SD/MI melalui Pembelajaran Tematik-Terpadu. Jurnal JPSD (Jurnal Pendidikan Sekolah Dasar), 1(1), 1-13.

Sagala, S. (2005). Konsep dan Makna Pembelajaran. Bandung: CV Alfabeta.

Sari, L. I., Satrijono, H., \& Sihono, S. (2015). Penerapan Model Pembelajaran Berbasis Projek (Project Based Learning) untuk Meningkatkan Hasil Belajar Keterampilan Berbicara Siswa Kelas VA SDN Ajung 03. Jurnal Edukasi, 2(1), 11-14.

Sukmadinata, Nana Syaodih. (2004). Kurikulum \& Pembelajaran Kompetensi. Bandung: PT. Remaja Rosdakarya . (2007). Metode penelitian pendidikan. Bandung: Roda.

Sundayana, Wachyu. (2014). Pembelajaran Berbasis Tema. Jakarta: Erlangga.

Trianto. (2009). Mendesain Model Pembelajaran Inovatif-Prograsif : Konsep, Landasan, dan Implementasi Pada Kurikulum Tingkat Satuan Pendidikan (KTSP). Jakarta: Prenada Media Group.

(2011). Desain Pengembangan Pembelajaran Tematik Bagi Usia Dini TK/RA \& Anak Usia Kelas Awal SD/MI. Jakarta: Prenada Media Group.

-. (2012). Model Pembelajaran Terpadu. Jakarta: PT Bumi Aksara. 